\title{
Lead Poisoning: Myoclonus Following Welding Exposure
}

\section{Intoxicação por Chumbo: Mioclonias após Exposição à Soldagem}

Rubens Gisbert CURY $\rrbracket^{1}$, Jorge Humberto MARIN², William Omar CONTRERAS LOPEZ ${ }^{3}$ Acta Med Port 2017 Dec;30(12):889-889 - https://doi.org/10.20344/amp.9398

Keywords: Lead Poisoning/complications; Myoclonus/chemically induced

Palavras-chave: Intoxicação por Chumbo/complicações; Mioclonia/induzida quimicamente

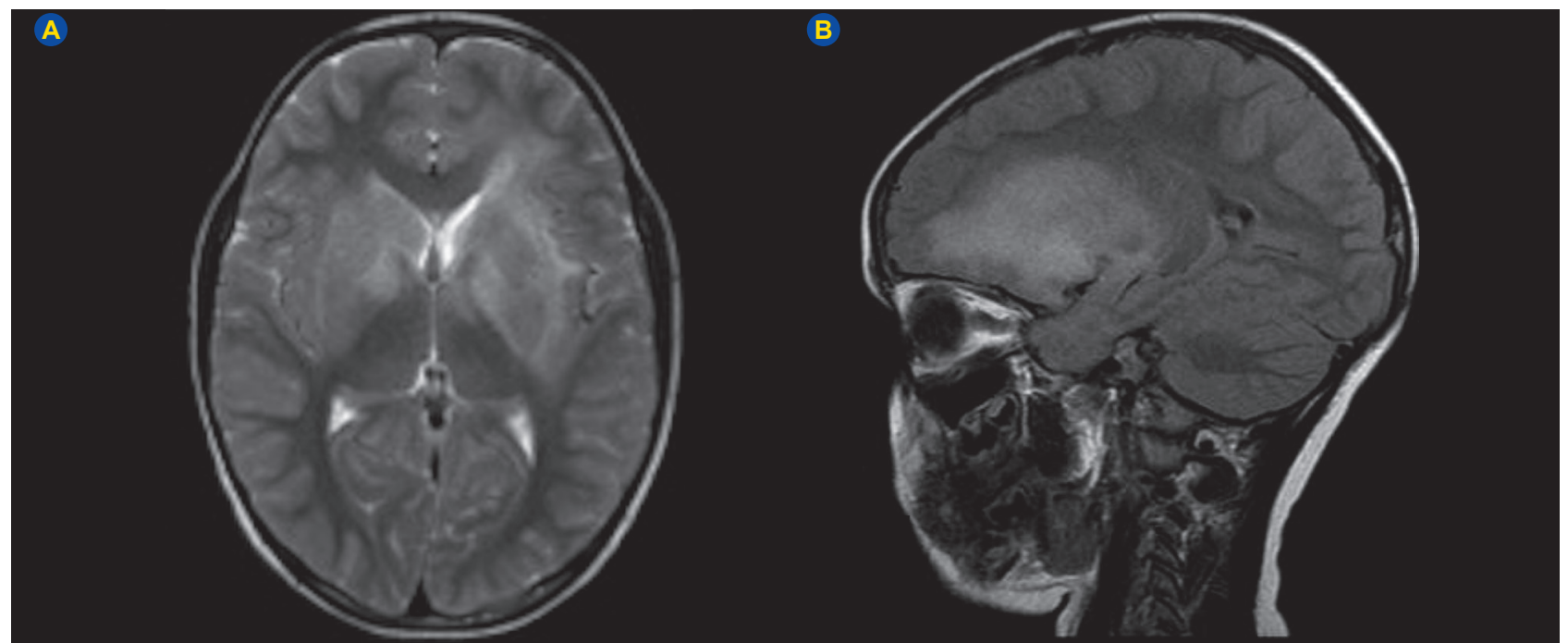

Figure 1 - Brain MRI. (A) Axial T2-weighted image showing bilateral hyperintensity of the basal ganglia with mass effect and corresponding; (B) sagittal view showing left frontal-subcortical involvement after lead toxicity

A previously healthy 5-year-old male presented with progressive anorexia, irritability, vomiting, mental confusion, insomnia and abnormal movements during the last 15 days. The family had moved three months before to a house adjacent to a welding garage. The neurological examination revealed a confusional state, impaired swallowing, grasp reflex, right hemiparesis, and generalized myoclonus. Magnetic resonance imaging showed bilateral basal ganglia and left frontal T2 hyperintensities (Fig. 1). Blood lead level was $27 \mu \mathrm{g} / \mathrm{dL}$ (normal $<5 \mu \mathrm{g} / \mathrm{dL}$ ). Chelation therapy reversed neurologic deficits.

Environmental lead exposure is a global health concern in children interfering with the cardiac, intestine, renal, reproductive and nervous system, causing potentially permanent damage. Brain lesions usually affect the hippocampus, frontal lobe and cerebellum. Basal ganglia involvement and myoclonus are rarely reported. ${ }^{1,2}$ Toxicity from other heavy metals such as manganese, mercury and cadmium are included in the differential diagnosis of lead poisoning, as well as acute demyelinating disease, viral encephalitis and metabolic disorders. ${ }^{3,4}$ Occupational history and environmental history are indispensable for the diagnosis.

\section{DATA CONFIDENTIALITY}

Informed consent was duly obtained from the legal representative of the patient.

\section{CONFLICTS OF INTEREST}

The authors report no financial disclosure related to this article.

\section{FUNDING SOURCES}

This project was not funded.

\section{REFERENCES}

1. Kennedy C, Lordo R, Sucosky MS, Boehm R, Brown MJ. Primary prevention of lead poisoning in children: a cross-sectional study to evaluate state specific lead-based paint risk reduction laws in preventing lead poisoning in children. Environ Health Glob Access Sci Source. $2014 ; 13: 93$.

2. Liu K, Hao J, Zeng Y, Dai F, Gu P. Neurotoxicity and biomarkers of lead exposure: a review. Chin Med Sci. 2013;28:178-88.

3. Cury RG, Lopez WOC. Bilateral striatal lesion due to herpesvirus-6 infection. J Neurol Sci. 2015;358:538-9.

4. Sahu JK, Sharma S, Kamate M, Kumar A, Gulati S, Kabra M, et al. Lead encephalopathy in an infant mimicking a neurometabolic disorder. J Child Neurol 2010;25:390-2.

1. Movement Disorders Center. Department of Neurology. School of Medicine. Universidade de São Paulo. São Paulo. Brazil.

2. Department of Radiology and Medical Imaging. School of Medicine San Jose. Bogota. Colombia.

3. Instituto de Epilepsia y Parkinson del Eje Cafetero SA. Pereira. Colombia

$\triangle$ Autor correspondente: Rubens Gisbert Cury. rubens_cury@terra.com.br

Recebido: 04 de julho de 2017 - Aceite: 19 de outubro de 2017 | Copyright @ Ordem dos Médicos 2017 